\title{
The Status and Role of Women in the Community of Suku Dayak Hindu Budha Bumi Segandhu Indramayu
}

\author{
P. Wulandari, A. Hufad, S. Nurbayani \\ Department of Sociology Education, Universitas Pendidikan Indonesia \\ Bandung, INDONESIA \\ puspitawulandari@student.upi.edu
}

\begin{abstract}
The community of Suku Dayak Hindu Budha Bumi Segandhu Indramayu values the status and role of women as being more important compared to that of men's. This study applied descriptive method and Spradley's analysis design to explain the phenomenon. The result of this study shows that the highest status and role of women in SDHBBSI are shaped through the concept of ngaula ning anak rabi. This concept obligates men to serve women, while liberating women from domestic work responsibilities. Further analysis of the concept reveals that the concept of ngaula ning anak rabi is originated from the local belief system.
\end{abstract}

Keyword: suku dayak hindu budha bumi segandhu indramayu, ngaula ning anak rabi, women's status and role in a society.

\section{INTRODUCTION}

A considerable amount of research has vividly described women in a global perspective. Some of the research shows that when women gain education, they become the center of attention (McPherson, 1996). Women are regarded as being inadequate to be involved in education. This phenomenon demonstrates how education is a taboo for women in the past. The various social changes taking place have, in fact, not transformed or even reduced the role and responsibilities of women in the domestic domain (Abdullah, 1985). Women continue to bear the highest responsibility for domestic-related jobs, highlighting discriminations against women in their restricted participation in public domains. The injustice experienced by women is a social construction, influenced by their social location, namely the global location where they reside; it unavoidably takes part in the cultivation of values regarding women and men, which will eventually determine the way people view the two genders. Gender diversity in a society is indeed closely linked to the culture of that society (Bernardi \& Threadgill, 2010).

More specifically, discussion on the role of women is inextricable from how ideas, beliefs, and cultures form women's collective actions in their social life (Baldez, 2003). There are values attached to women which position them as the inferior group. The values are socially constructed, inherent in each woman, and are regarded as the rights or nature of a woman. It is, for instance, women's nature to have a period, to conceive, and to breastfeed (Megawangi, 2001). Consequently, it is this "nature" that triggers the emasculation of women. There are several factors shaping the ways people view men and women, such as sexual relation, stereotypes of roles, education of roles, and division of domestic and public domains for the two sexes. However, it is too simplifying to think that the factors are constructed similarly across different societies and cultures. Cultures, belief systems, and social patterns form social concepts and practices in the realities of each society (Shah \& Shah, 2012).

Suku Dayak Hindu Budha Bumi Segandhu Indramayu has a unique view of the status and role of women. Women in this community occupy a noble status. The appreciation is underpinned by a belief that there will be no life without women. Women are regarded as strong and noble creatures due to the many things that God has given them, which are precisely the nature of women. The concept of ngaula ning anak rabi, which means the men in this community devote their lives for women (wives/mothers) and daughters, is a concept that underpins the noble status of women in this community.

Appreciation for women inherent in this community can be further revealed by looking at the definition of the name of this community itself, where Suku means foot, meaning that in meeting their goals, human beings should stand on their own feet; Dayak that comes from the word ayak or ngayak means to filter, sort, and select between the good and the wrong, in order to gain a lesson from them; Hindu, whose literal meaning is womb or uterus, means each human in this world is given birth to from a mother's or woman's womb; Budha that literally means wuda or naked, has the connotative meaning that each human being is born naked, without any string covering him or her; Bumi or form means that life exists; Segandhu, which is defined as the entire body, when combined with the word Bumi-Bumi Segandhu-means the power of life; and Indramayu that is derived from the word In or core, Darma or parents, and $A y u$ or beautiful or female, means women are the source of life, because from their wombs human beings are born into this world and form a civilization.

\section{THE STATUS AND ROLE OF WOMEN IN SUKU DAYAK HINDU BUDHA BUMI SEGANDHU INDRAMAYU}

The disparate views of women and men will not be revealed if no one is aware of them and studies their position in the social domain. Views on women are inextricably linked to the local people's view on sex itself and how to perceive women in their current positions (Gustafsson \& Björklund, 2008). The values attached to the women of Suku Dayak Hindu Budha Bumi Segandhu Indramayu reflect their noble position in the community, made possible by the concept of ngaula ning anak rabi. The men in this community totally devote themselves to women. This devotion is based on a belief that everything that currently exists originates from women. Women are 
the seeds of life. Without women, life will be non-existent. Women are beings and the giver of life, and men exist because of them. It is the women who conceive, give birth, and breastfeed. Although it is true that without men women will not possibly conceive, the role of men is limited to helping create the formation of the fetus. Without women, a family will not be formed; likewise, a society will be non-existent.

Suku Dayak Hindu Budha Bumi Segandhu Indramayu views women as strong beings. The view is based on a belief that the Almighty has blessed women with many things that men do not possess, namely the ability to have a period, to give birth, and to breastfeed, which cannot be possibly done by men. The belief that is cultivated and upheld strongly by this community about women has resulted in the noble status that women acquire. The nature of women, such as to have a period, to conceive, to give birth, and to breastfeed which commonly will cause women to be positioned as "the other", in fact, is what makes women acquire their noble position in this community. The following discussion on the role of women in the community of Suku Dayak Hindu Budha Bumi Segandhu Indramayu focuses on their functions at the levels of society and family.

\section{A. The Women of Suku Dayak Hindu Budha Bumi} Segandhu Indramayu in Their Society and Family

In a certain society, an individual has a number of statuses, where each of them bears its own roles. The status consequently influences an individual's position. The individual will acquire his or her rights and obligations, which are the implementation of his or her roles in relation to other individuals in the group or in a broader scope. For instance, in Malayu community, women are prepared to be wives and mothers. The destined positions will certainly carry with them certain domestic obligations that women must fulfill (Abdullah, 1985). Ruth Benedict (1934) states that culture is akin to an individual; it is more or less a consistent pattern of thoughts and actions. McPherson (1996) adds that women are constructed and positioned in a domain that is "safe" for them and for the "system", because women's status "is not to be questioned in a solid system and structure, where questioning their status will disturb the structure and status quo of the system of the oldest inequality in the society" (Fakih, 2013).

The women of Suku Dayak Hindu Budha Bumi Segandhu Indramayu can live their social life well. The inherently noble status that the community attaches to them does not make them negligent in their social life. The women of this community does not receive special treatments from the people around them, regardless of the different values the community attaches to the women compared to those of the surrounding communities. The women do the usual activities. However, uniqueness is found in the social life of this community, particularly in terms of politics. The people in this community, who are eligible by age to vote, do not participate in the election because they do not have the resident identity card (Indonesian, and henceforth, KTP) or their KTPs are no longer valid and they do not renew their KTPs. For Suku Dayak Hindu Budha Bumi Segandhu Indramayu, KTP is divided into two, the dead KTP and the living KTP. The administrative KTP issued by the government is a dead one, a mere sheet of paper which is meaningless if there is no money. On the other hand, the living KTP is the people themselves, who are there when somebody needs them.
If in general women are busied with domestic jobs without the help of men, the same is not true for the women of Suku Dayak Hindu Budha Bumi Segandhu Indramayu. They are not immersed in the domestic job; some of them are not even obligated to do it. The men in this community are used to doing the domestic job. In terms of intensity, it is found that men more frequently undertake the domestic job than women do. This phenomenon is the implementation of the ngaula ning anak rabi concept, based on the teaching of ngaji rasa, namely to examine feelings, to sort and select what is good from the wrong by means of self-introspection and appreciation of life values. To err is human, but human beings are given opportunities to fix it through learning process, namely learning to gain a lesson from each error and learning to gain meanings for each error made.

Suku Dayak Hindu Budha Bumi Segandhu Indramayu is familiar with three elements of life harmony (rukun hidup): first, the family harmony or harmony in the household (rukun tangga); second, the social harmony or harmony in social life (rukun warga); and third, religious harmony or harmony in religious life (rukun agama). The household/family harmony is the underlying harmony in realizing harmony in life. Ngaula ning anak rabi is the way to realize this harmony. The people view that once harmony in the household is realized, harmony in social and religious life will be consequently realized.

The noble values attached to the women in this community have an effect on the daily activities, ultimately in terms of job sharing with men in the economic activities. The women in this community are not burdened with domestic, but public jobs. They are given the freedom to choose which domain to take, whether the domestic or the public one. All of their activities, both in and outside the house, are done based on their desires, without any force from the men.

\section{B. The Women of Suku Dayak Hindu Budha Bumi \\ Segandhu Indramayu in the Field of Education}

The quality of life and the socio-economic condition will improve if the society has maximized the role of education. Through education, capable and quality human beings can be created in the context of holistic development. Well-educated women will increase the opportunities for similarly good education for their children. Nevertheless, in reality the number of women receiving education is significantly smaller than that of men, so that it is clear that in terms of education women lag behind men (Hendratmoko, 2011). Peter Hagul (in Wirawan, n.d) explains that when children have greater values than their parents, it will be difficult for women to liberate themselves from the domestic role they have. This problem is what causes the improvement of a mother's status even more difficult (Wirawan, n.d.)

The women of Suku Dayak Hindu Budha Bumi Segandhu Indramayu are categorized into low-educated people. The freedom that their children have in choosing the best for their life, including education, lies solely in the children. The noble values the community attaches to women and children, in fact, are not directly proportional to their participation in the education and public domains. The cultivation of the value of ngaula ning anak rabi among Suku Dayak Hindu Budha Bumi Segandhu Indramayu can be said to resemble a double-edged knife. On the one hand, the values result in men's devotion to their wives and children; but on the other hand, it is the 
devotion that eliminates children's obligations to gain education.

\section{DISCUSSION: ANALYSIS WITH SPRADLEY'S ETHNOGRAPHIC METHOD}

What follow is a discussion of the findings employing Spradley's Method of Ethnography (Spradley, 2007).

\section{A. Domain Analysis}

The type of domain found in this research on the status and role of the women of Suku Dayak Hindu Budha Bumi Segandhu Indramayu is folk domain, which is a term born out of the language used in the society in their social life. The analysis of meaning will be found in the semantic column, while the analysis of the meaning in more depth is presented in the Meaning Analysis column.

TABLE I. THE CONCEPT OF SUKU DAYAK HINDU BUdHA BUMI SEGANDHU INDRAMAYU

\begin{tabular}{|l|l|l|}
\hline \multicolumn{3}{|c|}{ Belief } \\
\hline People Domain & \multicolumn{1}{|c|}{ Semantic } & \multicolumn{1}{c|}{ Meaning Analysis } \\
\hline ngaula & Devotion & Sincerity \\
ning & in / to & place / destination \\
rabi & Wife & Women and children \\
ngaji & Reading & Learning to understand \\
& & meaning \\
\hline
\end{tabular}

TABLE II. IDENTITY IN SUKU DAYAK HINDU BUDHA BUMI SEGANDHU INDRAMAYU

\begin{tabular}{|l|l|l|}
\hline \multicolumn{3}{|c|}{ Identity Description } \\
\hline People Domain & \multicolumn{1}{|c|}{ Semantic } & \multicolumn{1}{c|}{ Meaning Analysis } \\
\hline Living KTP & $\begin{array}{l}\text { The human } \\
\text { beings } \\
\text { themselves } \\
\text { Administrative } \\
\text { card }\end{array}$ & $\begin{array}{l}\text { Real } \\
\text { tangible/visible } \\
\text { (human beings) } \\
\text { Quasi sign, intangible } \\
\text { (invisible for human } \\
\text { beings) }\end{array}$ \\
\hline
\end{tabular}

TABLE III. THE HARMONY OF LIFE IN SUKU DAYAK HINDU BUDHA BUMI SEGANDHU INDRAMAYU

\begin{tabular}{|c|c|c|}
\hline \multicolumn{3}{|c|}{ Life Harmony } \\
\hline $\begin{array}{c}\text { People } \\
\text { Domain }\end{array}$ & Semantic & Meaning Analysis \\
\hline $\begin{array}{l}\text { Family } \\
\text { harmony }\end{array}$ & Family & Harmony in family life \\
\hline $\begin{array}{l}\text { Social } \\
\text { harmony }\end{array}$ & Society & Harmony in social life \\
\hline $\begin{array}{l}\text { Religious } \\
\text { harmony }\end{array}$ & Religion & $\begin{array}{l}\text { Harmony in religious } \\
\text { life }\end{array}$ \\
\hline
\end{tabular}

TABLE IV. WOMEN'S NOBLE VALUES IN SUKU DAYAK HiNDU BUDHA BUMI SEGANDHU INDRAMAYU

\begin{tabular}{|c|l|l|}
\hline \multicolumn{1}{|c|}{ Women's Noble Values } \\
\hline $\begin{array}{c}\text { Pomain } \\
\text { ngaji rasa }\end{array}$ & $\begin{array}{l}\text { Semantic } \\
\text { Analyzing, } \\
\text { appreciating } \\
\text { the feelings } \\
\text { in the mind }\end{array}$ & $\begin{array}{l}\text { Meaning Analysis } \\
\text { filtering the good from } \\
\text { the wrong in an } \\
\text { attempt of finding the } \\
\text { truth }\end{array}$ \\
$\begin{array}{l}\text { ngaula ning } \\
\text { anak rabi }\end{array}$ & $\begin{array}{l}\text { Devoted to } \\
\text { children and } \\
\text { wife }\end{array}$ & $\begin{array}{l}\text { Husband's devotion to } \\
\text { his children and wife }\end{array}$ \\
\hline
\end{tabular}

\section{B. Taxonomy Analysis}

Taxonomy analysis is obtained from the elaboration of the domain. This analysis is aimed at finding the internal structure of each domain, in which the analysis is undertaken to each stage of the domain. The resulting taxonomy obtained from the analysis is more focused than the result obtained from the previous stage.
TABLE V. THE CONCEPTS OF SUKU DAYAK HINDU BUDHA BUMI SEGANDHU INDRAMAYU

\begin{tabular}{|l|l|}
\hline \multicolumn{2}{|c|}{ Belief } \\
\hline \multicolumn{1}{|c|}{ Domain } & \multicolumn{1}{c|}{ Taxonomy } \\
\hline \multirow{2}{*}{ angaula ning rabi } & Devotion to women \\
\cline { 2 - 2 } & Devotion to children \\
\cline { 2 - 2 } & Women's noble values \\
\cline { 2 - 2 } & ngaji rasa \\
\hline
\end{tabular}

TABLE VI. TYPES OF IDENTITY IN SUKU DAYAK HINDU BUDHA

\begin{tabular}{|c|l|}
\hline \multicolumn{2}{|c|}{ BUMI SEGANDHU INDRAMAYU } \\
\hline Domain & \multicolumn{1}{c|}{ Taxonomy } \\
\hline \multirow{2}{*}{ Living KTP } & Human beings \\
\cline { 2 - 2 } & Human beings themselves \\
\cline { 2 - 2 } & Tangible signs \\
\hline \multirow{3}{*}{ Dead KTP } & Administrative card \\
\cline { 2 - 2 } & Useless without the owner \\
\cline { 2 - 2 } & Unable to help people in need \\
\cline { 2 - 2 } & Meaningless without money \\
\hline
\end{tabular}

TABLE VII. THE LIFE HARMONY IN SUKU DAYAK HINDU BUDHA BUMI SEGANDHU INDRAMAYU

\begin{tabular}{|l|l|}
\hline \multicolumn{2}{|c|}{ Life Harmony } \\
\hline \multicolumn{1}{|c|}{ Domain } & \multicolumn{1}{|c|}{ Taxonomy } \\
\hline \multirow{4}{*}{ Family } & Family \\
\cline { 2 - 2 } & Women or wives \\
\cline { 2 - 2 } & Men or husbands \\
\cline { 2 - 2 } Social & Children \\
\cline { 2 - 2 } & The concept of ngaula ning anak rabi \\
\hline \multirow{5}{*}{$\begin{array}{l}\text { Religious } \\
\text { harmony }\end{array}$} & Society \\
\cline { 2 - 2 } & $\begin{array}{l}\text { Diverse but united } \\
\text { finding the truth }\end{array}$ \\
\cline { 2 - 2 } & Belief \\
\cline { 2 - 2 } & $\begin{array}{l}\text { Diversity in beliefs } \\
\text { Respect for different ways of finding } \\
\text { the truth }\end{array}$ \\
\cline { 2 - 2 } & $\begin{array}{l}\text { Life is a learning process in finding the } \\
\text { truth }\end{array}$ \\
\hline
\end{tabular}

TABLE VIII. THE NOBLE VALUES OF WOMEN IN SUKU DAYAK HINDU BUDHA BUMI SEGANDHU INDRAMAYU

\begin{tabular}{|l|l|}
\hline \multicolumn{2}{|c|}{ The Noble Values of Women } \\
\hline Domain & \multicolumn{1}{c|}{ Taxonomy } \\
\hline \multirow{5}{*}{ Women } & Source of life \\
\cline { 2 - 2 } & "Natural layer" \\
\cline { 2 - 2 } & $\begin{array}{l}\text { Strong beings (menstruation, conceive, } \\
\text { give birth, and breastfeed) }\end{array}$ \\
\cline { 2 - 2 } & $\begin{array}{l}\text { Freedom in choosing the activities in } \\
\text { life }\end{array}$ \\
\cline { 2 - 2 } & Devotion from husband \\
\hline
\end{tabular}

\section{Componential Analysis}

After discovering the internal structure of each domain in this research through taxonomy analysis, the next stage is searching for units of meanings. The search for units of meanings is done in the stage of componential analysis. The researchers search for unit of meanings in the categories of cultures practiced by the research subjects. The purpose of componential analysis is to find the more specific characteristics of each internal structure, or in a simpler term, the researchers look for components of meanings gained through the stage of taxonomy analysis. Subsequently, the components of meanings are associated into the categories of culture.

1) The Concepts of Suku Dayak Hindu Budha Bumi Segandhu Indramayu
a) ngaula ning anak rabi
b) ngaji rasa

2) Identity Descriptions 
a) Living KTP

b) Dead KTP

3) Life Harmony
a) Family harmony
b) Social harmony
c) Religious harmony

4) Women's Values

a) The meaning of Suku Dayak Hindu Budha Bumi Segandhu Indramayu

b) Daily activities in the domestic domain

5) Women
a) Noble values
b) Devotion from husband
c) Freedom in choice

\section{Cultural Theme Analysis}

Cultural theme is obtained when the researchers are able to see the real phenomena during the research. People's statement, proverbs, mottos, or repeated expressions are categorized by the researchers into more general and higher level categories. The researchers delve into the implied meanings in each phenomenon observed during research. The cultural themes obtained in the research on the status of the women of Suku Dayak Hindu Budha Bumi Segandhu Indramayu are as follows: Women are the source of life.

- Women are "the natural layer" or essential part of the nature

- Devotion to women and children is the means of realizing harmony in the household.

- Devotion to women and children is a way of selfintrospection and finding the truth in life.

The cultural themes discovered in this research regarding the roles of the women of Suku Dayak Hindu Budha Bumi Segandhu Indramayu are:

- The real Resident ID Card is the human beings themselves.

- Family harmony is the foundation in realizing social harmony.

- Social harmony is the basis of religious harmony.

- Religious harmony is the ultimate harmony among human beings.

\section{CONCLUSION}

Sexual differences frequently give birth to gender inequalities, manifested in the ways of perceiving, valuing, and distributing the roles and status between women and men in the domestic and public domains. The subordination, marginalization, stereotype, and burdensome workload of women are subverted by the values attached to women, upheld and implemented by Suku Dayak Hindu Budha Bumi Segandhu Indramayu (SDHBBSI). The nature aspect of women, such as menstruation, conceiving, giving birth, and breastfeeding in SDHBBSI becomes the foundation for positioning women in the noble status. Women empowerment, especially in the field of education, is really needed in order to balance the noble values of Suku Dayak Hindu Budha Bumi Segandhu Indramayu through participation in a broader scope of the public domain.

\section{ACKNOWLEDGEMENTS}

The main researcher would like to express her sincere gratitude to Prof. Dr. Achmad Hufad, M.Ed and Dr. Hj. Siti Nurbayani K, M.Si., who have supervised and helped the completion of this research. A deep appreciation is extended to the community of Suku Dayak Hindu Budha Bumi Segandhu Indramayu, particularly Takmad Diningrat, as the Head of the Community, and Rusdi, who has been really helpful in providing the necessary information for the research.

\section{REFERENCES}

[1] Baldez, L. (2003). Womens Movements and Democratic Transition in Chile, Brazil, East Germany and Poland. Comparative Politics, 253-272.

[2] Bernardi, \& Threadgill. (2010). Women directors and corporate social responsibility. Electronic Journal of Business Ethics and Organization Studies, 15(2), 15-21.

[3] Gustafsson, U., \& Björklund, F. (2008). Women self-stereotype with feminine stereotypical traits under stereotype threat. Current Research in Social Psychology, 13(18), 219-231.

[4] McPherson, N. M. (1996). Women Writing Culture. Anthropologica.

[5] Pekerjaan, W. D. A. N., Analisis, S., Peranan, K., \& Abdullah, F. (1985). WANITA DAN PEKERJAAN:, (27).

[6] Shah, S., \& Shah, U. (2012). Women, Educational Leadership and Societal Culture. Education Sciences.

[7] Hendratmoko, C. (2011). Permasalahan Pendidikan Pada NegaraNegara. Vol, G., \& Maret, E. 37-41.

[8] Wirawan, I. B. (n.d.). Status Wanita dalam Perspektif Kajian Studi Kependudukan.

[9] Fakih, M. (2013). Analisis Gender dan Transformasi Sosial. Yogyakarta: Pustaka Pelajar.

[10] Megawangi, R. (2001). Membiarkan Berbeda? Bandung: Penerbit Mizan.

[11] Spradley, J. P. (2007). Metode Etnografi. (edisi kedua). Yogyakarta: Tiara Wacana. 